\title{
FAKTOR-FAKTOR YANG BERHUBUNGAN DENGAN PELAKSANAAN INFORMED CONSENT DI RUANG RAWAT INAP RSUD DR M.YUNUS BENGKULU TAHUN 2011
}

\author{
Septiyanti, Gusnilawati, Nur Elly \\ Jurusan Keperawatan Poltekkes Kemenkes Bengkulu Jl. Indragiri No.3 Bengkulu \\ Jurusan Keperawatan Poltekkes Kemenkes Bengkulu Jl. Indragiri No.3 Bengkulu \\ Jurusan Keperawatan Poltekkes Kemenkes Bengkulu Jl. Indragiri No.3 Bengkulu
}

\begin{abstract}
Informed consent is an agreement by the patient to receive the treatment of or after the procedure provides more information, including the benefits and risks of treatment, alternative treatment, and prognosis. Based on the experiences during the service-man research at the Regional General Hospital (Hospital) Dr. M. Yunus Bengkulu nurse practitioner nursing action, just tell the nurse will be nursing actions and explain the aims of action, then ask for approval. So most patients and families do not know the side effects of actions, alternatives, risks and prognosis Tinda her. The study design was cross-sectional. Study sample were all nurses in the inpatient implementers: Jasmine, Chrysanthemum, and Lotus Hospital Flamboyan M Yunus Bengkulu in 2011, totaling 95 people. Univariate analysis was done with the frequency distribution, the bivariate chi-square test, and multivariate logistic regression models of multiple confounding. The results showed that almost all $(76.8 \%)$ gave informed concent is not complete. Only leadership style variable-gammer mempu significant association with the implementation of informed consent $(\mathrm{p}=0.02)$. Only the age variable to be confounding variables. Expected to carry out the briefing room head every morning with the nurse practitioner, the more stressed implementation of informed consent on each will implement nursing actions.
\end{abstract}

\begin{abstract}
Abstrak : Informed consent adalah suatu persetujuan dengan pasien untuk menerima peng-obatan atau prosedur setelah menyediakan informasi lengkap, termasuk manfaat dan risiko pengobatan, alternatif pengobatan, dan prognosis. Berdasarkan pengala-man peneliti selama dinas di Rumah Sakit Umum Daerah (RSUD) Dr. M. Yunus Bengkulu, pada saat perawat pelaksana melakukan tindakan keperawatan, perawat hanya memberitahukan akan dilakukan tindakan keperawatan dan menjelaskan tu-juan tindakan, kemudian meminta persetujuan. Sehingga sebagian besar pasien dan keluarga tidak mengetahui efek samping tindakan, alternatif lain, risiko tinda-kan dan prognosis. Desain penelitian adalah cross sectional. Sampel penelitian adalah semua perawat pelaksana di ruang rawat inap: Melati, Seruni, Flamboyan dan Teratai RSUD M Yunus Bengkulu tahun 2011, berjumlah 95 orang. Analisis dilakukan secara univariat dengan distribusi frekuensi, bivariat dengan uji chi-square, dan multivariat dengan regresi logistik ganda model confounding. Hasil penelitian menunjukkan bahwa hampir seluruh $(76,8 \%)$ memberikan informed concent secara tidak lengkap. Hanya variabel gaya kepemimpinan yang mempu-nyai hubungan signifikan dengan pelaksanaan informed consent $(\mathrm{p}=0,02)$. Hanya variabel umur menjadi variabel confounding. Diharapakan kepala ruangan dapat melaksanakan briefing setiap pagi dengan perawat pelaksana, dengan lebih mene-kankan pelaksanaan informed consent pada setiap akan melaksanakan tindakan keperawatan.
\end{abstract}

Kata Kunci : Gaya kepemimpinan, Informed consent

Perawat adalah seseorang profesional yang mempunyai keterampilan, tanggung jawab dan kewenangan melaksanakan pelayanan keperawatan. Tenaga perawat merupakan "The caring profession" mempunyai kedudukan penting dalam menghasilkan kualitas pelayanan kesehatan dirumah sakit (Departemen Kesehatan RI, 2001). Seka- rang sistem pelayanan perawat Indonesia mengalami perkembangan yang sebelumnya dikatakan sebagai tenaga vokasional berubah menjadi tenaga profesional, sehingga profesi tersebut mengemban tanggung jawab yang besar serta memiliki sikap, pengetahuan dan keterampilan yang memadai agar nantinya dapat diterapkan 
pada asuhan keperawatan sesuai dengan standar berdasarkan kode etik profesi (Kusnanto, 2004).

Acuan dalam menilai kualitas pelayanan keperawatan adalah dengan menggunakan standar praktik keperawatan. Standar praktik ini menjadi pedoman bagi perawat dalam melaksanakan asuhan keperawatan. Kualitas pelayanan keperawatan suatu rumah sakit dinilai dari kepuasan pasien yang sedang atau pernah dirawat (Wijono, 2003).

Salah satu tindakan keperawatan dalam pelayanan keperawatan adalah pelaksanaan informed consent (Dunn, 1999). Klien memiliki hak untuk menentukan keputusan tentang perawatan yang mereka terima. Klien dapat mengubah pikiran mereka dan membatalkan prosedur kapan saja karena hak untuk menolak selalu berlaku bahkan setelah menandatangani persetujuan (Sullivan, 1998)

Berdasarkan pengalaman peneliti selama dinas di Rumah Sakit Umum Daerah (RSUD) Dr. M. Yunus Bengkulu, pada saat perawat pelaksana melakukan tindakan keperawatan, perawat hanya memberitahukan akan dilakukan tindakan keperawatan dan menjelaskan tujuan tindakan, kemudian meminta persetujuan. Sehingga tidak sedikit pasien dan keluarga pasien yang tidak mengetahui efek samping tindakan, alternatif lain, resiko tindakan dan kemungkinan-kemungkinan yang terjadi bila tidak dilakukan tindakan.

Kinerja seorang perawat dapat dilihat dari mutu asuhan keperawatan yang di berikan pada pasien. Menurut Ilyas (2001) kinerja merupakan penampilan hasil karya individu maupun kelompok kerja baik secara kuantitas maupun kualitas dalam suatu organisasi. Menurut Hall TL dan Meija (1987) dalam Ilyas (2001) faktor yang mempengaruhi kinerja adalah: faktor internal individu yang terdiri dari: (1) karakteristik individu, seperti: umur, pendapatan, status perkawinan, pengalaman kerja dan masa kerja. (2) Sikap terhadap tugas, seperti: persepsi, pengetahuan, motivasi, tanggung-jawab dan kebutuhan terhadap imbalan, sedang faktor eksternal meliputi sosial ekonomi, demografi, geografi, lingkungan kerja, aseptabilitas, aksesabilitas, beban kerja dan organisasi yang terdiri pembinaan, pengawasan, koordinasi, dan fasilitas.

Berdasarkan survei awal yang dilakukan peneliti pada dua ruang rawat inap yang berbeda. Pengamatan dilakukan terhadap 3 orang perawat pelaksana di masing-masing ruangan. Pada ruangan pertama, diketahui bahwa $(67,7 \%)$ perawat hanya menjelaskan tindakan yang akan dilakukan dan tujuan, sedangkan $(32,3 \%)$ menambahkan penjelasannya sampai resiko bila tidak dilakukan tindakan. Informed consent yang disampaikan tidak menjelaskan efek samping tindakan, alternatif lain, resiko tindakan dan kemungkinan-kemungkinan yang terjadi bila tidak dilakukan tindakan. Sehingga pasien dan keluarga, merasa tidak puas dengan penjelasan yang diberikan dan merasa keharusan untuk menandatangani surat pernyataan. Ketiga perawat pelaksana yang diamati di ruangan pertama, hanya meminta persetujuan lewat lisan, tidak meminta persetujuan secara tertulis.

Pada ruangan kedua, diketahui bah-wa hanya $(32,3 \%)$ perawat menjelaskan tindakan yang akan dilakukan, tujuan dan resiko bila tidak dilakukan tindakan. Sedangkan $(67,7 \%)$ perawat sudah melaksanakan tahapan informed consent dan meminta persetujuan secara tertulis kepada pasien. Tujuan Penelitian ini adalah diketahuinya faktor-faktor yang berhubungan dengan pelaksanaan informed consent diruang rawat inap RSUD Dr. M.Yunus Bengkulu tahun 2011.

\section{BAHAN DAN CARA KERJA}

Penelitian ini merupakan penelitian analitik dengan menggunakan desain cross sectional. Populasi penelitian adalah semua perawat pelaksana di ruang rawat inap: Melati, Seruni, Flamboyan dan Teratai RSUD M Yunus Bengkulu tahun 2011. Jumlah populasi menggunakan gambaran 
jumlah perawat pelaksana di ruang rawat inap: Melati, Seruni, Flamboyan dan Teratai RSUD M Yunus Bengkulu tahun 2010, sebanyak 95 orang. Sampel penelitian adalah total populasi dengan Kriteria inklusi adalah: kooperatif (bersedia menjadi responden). Kriteria eksklusi: perawat pelaksana dalam keadaan cuti selama pengumpulan data penelitian. Analisis data yang dilakukan adalah Analisis univariat, bivariat dengan uji Chi-Square $\left(\chi^{2}\right)$, multivariat yang digunakan adalah Logistic Regression Ganda dengan model confounding.

HASIL

\section{Analisis Univariat}

Ukuran distribusi frekuensi menjelaskan tentang berapa sering suatu masalah kesehatan terjadi. Hasil analisis univariat dapat dilihat pada tabel 1

Tabel 1: Distribusi Frekuensi Responden Berdasarkan Pengetahuan, Motivasi, Gaya Kepempinan, Umur, Lama Kerja, Jenis Kelamin dan Informed Concent di RSUD DR. M. Yunus Bengkulu Tahun 2011

\begin{tabular}{lcc}
\hline \multicolumn{1}{c}{ Variabel } & Frekuensi (f) & Persentase (\%) \\
\hline Pengetahuan & 31 & 32,6 \\
1. Kurang & 38 & 40,0 \\
2. Cukup & 26 & 27,4 \\
3. Baik & & 90,5 \\
Motivasi & 86 & 9,5 \\
1. Rendah & 9 & 57,9 \\
2. Tinggi & & 42,1 \\
Gaya kepemimpinan & 55 & \\
1. Otoriter dan partisipatif & 40 & 55,8 \\
2. Demokratis & & 44,2 \\
Umur & 53 & 56,8 \\
1. $\leq$ median & 42 & 43,2 \\
2. median & & \\
Lama kerja & 54 & 82,1 \\
1. Baru & 41 & 17,9 \\
2. Lama & & 76,8 \\
Jenis kelamin & 78 & 23,2 \\
1. Perempuan & 17 & \\
2. Laki-laki & & \\
Informed concent & 73 & \\
1. Tidak lengkap & 22 & \\
2. Lengkap & & \\
\hline
\end{tabular}

Tabel 1 menunjukkan bahwa dari 95 perawat pelaksana di ruang rawat inap RSUD DR. M. Yunus Bengkulu, diketahui bahwa: hampir sebagian $(32,6 \%)$ mempunyai pengetahuan kurang, hampir seluruh $(90,5 \%)$ mempunyai motivasi rendah, sebagian besar $(57,9 \%)$ mempunyai gaya kepemimpinan otoriter dan partisipatif, sebagian besar $(55,8 \%)$ mempunyai umur $\leq$ median, sebagian besar $(56,8 \%)$ mempunyai lama kerja yang termasuk baru, hampir seluruh $(82,1 \%)$ berjenis kelamin perempuan dan hampir seluruh $(76,8 \%)$ memberikan informed concent secara tidak lengkap.

\section{Analisis Bivariat}

Analisis bivariat dilakukan untuk melihat hubungan satu variabel independen (pengetahuan, motivasi, gaya kepemimpinan, umur, lama kerja, jenis kelamin) dengan variabel dependen (informed concent) di RSUD DR. M. Yunus Bengkulu tahun 2011. Analisis bivarat dilakukan dengan uji Chi-Square $\left(\chi^{2}\right)$, dengan derajat kemaknaan sebesar 5\% $(\alpha=0,05)$. Hasil analisis bivariat dapat dilihat pada tabel 2 . 
Tabel 2. Hasil Analisis Bivariat Hubungan: Pengetahuan, Motivasi, Gaya Kepemimpinan, Umur, Lama Kerja, Jenis Kelamin dengan Informed Concent di RSUD DR. M. Yunus Bengkulu Tahun 2011

\begin{tabular}{|c|c|c|c|c|c|c|c|c|c|}
\hline \multirow[t]{2}{*}{ Variabel } & \multicolumn{2}{|c|}{$\begin{array}{c}\text { Dengan } \\
\text { Informed } \\
\text { Concent }\end{array}$} & \multicolumn{2}{|c|}{$\begin{array}{c}\text { Tanpa } \\
\text { Informed } \\
\text { Concent }\end{array}$} & \multicolumn{2}{|l|}{$\begin{array}{c}\text { Juml } \\
\text { ah }\end{array}$} & \multirow[t]{2}{*}{ Nilai p } & \multirow[t]{2}{*}{$\overline{\text { PR }}$} & \multirow[t]{2}{*}{$95 \% \mathrm{CI}$} \\
\hline & $\mathrm{f}$ & $\%$ & $\mathrm{f}$ & $\%$ & $\mathrm{~F}$ & $\%$ & & & \\
\hline \multicolumn{10}{|l|}{ Pengetahuan } \\
\hline 1. Kurang & 23 & 74,2 & 8 & 25,8 & 31 & 100 & 0,84 & - & - \\
\hline 2. Cukup & 29 & 76,3 & 9 & 23,7 & 38 & 100 & & & \\
\hline 3. Baik & 21 & 80,8 & 5 & 19,2 & 26 & 100 & & & \\
\hline \multicolumn{10}{|l|}{ Motivasi } \\
\hline 1. Rendah & 66 & 76,7 & 20 & 23,3 & 86 & 100 & 1,00 & 0,94 & $0,18-4,91$ \\
\hline 2. Tinggi & 7 & 77,8 & 2 & 22,1 & 9 & 100 & & & \\
\hline \multicolumn{10}{|l|}{ Gaya kepemimpinan } \\
\hline 1. Otoriter dan partisipatif & 47 & 85,5 & 8 & 14,5 & 55 & 100 & 0,02 & 3,16 & $1,17-8,53$ \\
\hline 2. Demokratis & 26 & 65,0 & 14 & 35,0 & 40 & 100 & & & \\
\hline \multicolumn{10}{|l|}{ Umur } \\
\hline 1. $\leq$ median & 38 & 71,7 & 15 & 28,3 & 53 & 100 & 0,18 & 0,51 & $0,19-1,39$ \\
\hline 2. $>$ median & 35 & 83,3 & 7 & 16,7 & 42 & 100 & & & \\
\hline \multicolumn{10}{|l|}{ Lama kerja } \\
\hline 1. Baru & 44 & 81,5 & 10 & 18,5 & 54 & 100 & 0,22 & 1,82 & $0,70-4.76$ \\
\hline 2. Lama & 29 & 70,7 & 12 & 29,3 & 41 & 100 & & & \\
\hline \multicolumn{10}{|l|}{ Jenis kelamin } \\
\hline 1. Perempuan & 61 & 78,2 & 17 & 21,8 & 78 & 100 & 0,53 & 1,50 & $0,46-4,84$ \\
\hline 2. Laki-laki & 12 & 70,6 & 5 & 29,4 & 17 & 100 & & & \\
\hline
\end{tabular}

\section{Hubungan Pengetahuan dengan Informed} Concent.

Hasil analisis bivariat menunjukkan bahwa dari 31 perawat pelaksana mempunyai pengetahuan kurang, sebagian besar $(74,2 \%)$ tidak lengkap dalam memberikan informed concent; dari 38 perawat pelaksana mempunyai pengetahuan cukup, sebagian besar $(76,3 \%)$ tidak lengkap dalam memberikan informed concent; dan dari 26 perawat pelaksana mempunyai pengetahuan baik, sebagian besar $(80,8 \%)$ tidak lengkap dalam memberikan informed concent.

Hasil analisis dengan uji chi square didapatkan nilai-p 0,84, tidak ada hubungan secara signifikan pengetahuan dengan pemberian informed concent di RSUD dr. M. Yunus Bengkulu tahun 2011.

\section{Hubungan Motivasi dengan Informed Concent}

Hasil analisis bivariat menunjukkan bahwa dari 86 perawat pelaksana mempunyai motivasi rendah, sebagian besar $(76,7 \%)$ tidak lengkap dalam memberikan informed concent; dan dari 9 perawat pelaksana mempunyai motivasi tinggi, seba- gian besar $(77,8 \%)$ tidak lengkap dalam memberikan informed concent.

Hasil analisis dengan uji chi square didapatkan nilai-p 1,00, tidak ada hubungan secara signifikan motivasi dengan pemberian informed concent di RSUD dr. M. Yunus Bengkulu tahun 2011.

\section{Hubungan Gaya Kepemimpinan dengan Informed Concent.}

Hasil analisis bivariat menunjukkan bahwa dari 55 perawat pelaksana yang dibawah gaya kepemimpinan otoriter dan partisipatif, hampir seluruhnya $(85,5 \%)$ tidak lengkap dalam memberikan informed concent; dan dari 40 perawat pelaksana mempunyai yang dibawah gaya kepemimpinan demokratis, sebagian besar $(65,0 \%)$ tidak lengkap dalam memberikan informed concent.

Hasil analisis dengan uji Chi square didapatkan nilai-p 0,02, ada hubungan secara signifikan gaya kepemimpinan dengan pemberian informed concent di RSUD DR. M. Yunus Bengkulu tahun 2011. PR 3,16, artinya gaya kepemimpinan otoriter dan partisipatif mempunyai resiko sebesar 3,16 kali untuk pemberian informed concent tidak lengkap, dibanding- 
kan gaya kepemimpinan demokratis, di RSUD DR. M. Yunus Bengkulu tahun 2011.

\section{Hubungan Umur dengan Informed Concent.}

Hasil analisis bivariat menunjukkan bahwa dari 53 perawat pelaksana mempunyai umur $\leq$ median, sebagian besar $(71,7 \%)$ tidak lengkap dalam memberikan informed concent; dan dari 42 perawat pelaksana yang mempunyai umur > median, hampir seluruh $(83,3 \%)$ tidak lengkap dalam memberikan informed concent.

Hasil analisis dengan uji Chi square didapatkan nilai-p 0,28 , tidak ada hubungan secara signifikan umur dengan pemberian informed concent di RSUD DR. M. Yunus Bengkulu tahun 2011.

\section{Hubungan Masa Kerja dengan Informed Concent.}

Hasil analisis bivariat menunjukkan bahwa dari 54 perawat pelaksana yang mempunyai masa kerja yang lama, hampir seluruh $(81,5 \%)$ tidak lengkap dalam memberikan informed concent; dan dari 41 perawat pelaksana yang mempunyai masa kerja yang baru, sebagian besar $(70,7 \%)$ tidak lengkap dalam memberikan informed concent.
Hasil analisis dengan uji Chi square didapatkan nilai-p 0,325, tidak ada hubungan secara signifikan masa kerja dengan pemberian informed concent di RSUD dr. M. Yunus Bengkulu tahun 2011.

\section{Hubungan Jenis Kelamin dengan Informed Con- Cent.}

Hasil analisis bivariat menunjukkan bahwa dari 78 perawat pelaksana yang berjenis kelamin perempuan, hampir seluruh $(78,2 \%)$ tidak lengkap dalam memberikan informed concent; dan dari 17 perawat pelaksana yang berjenis kelamin laki-laki, sebagian besar $(70,6 \%)$ tidak lengkap dalam memberikan informed concent.

Hasil analisis dengan uji chi square didapatkan nilai-p 0,532, tidak ada hubungan secara signifikan jenis kelamin dengan pemberian informed concent di RSUD DR. M. Yunus Bengkulu tahun 2011.

\section{Analisis Multivariat}

Adapun variabel yang dapat masuk dalam analisis multivariat adalah: gaya kepemimpinan (nilai $\mathrm{p}=0,037$ ). Sedangkan variabel umur (nilai $\mathrm{p}=0,276$ ) dan masa kerja (nilai $\mathrm{p}=0,325$ ) dicoba dimasukkan ke dalam model karena diduga sebagai confounder. Sehingga hasil analisis adalah:

Tabel 3. Hasil Analisis Confounding dalam Faktor-Faktor yang Mempengaruhi Pelak-sanaan Informed Concent di RSUD Dr. M. Yunus Bengkulu Tahun 2011

\begin{tabular}{|c|c|c|c|}
\hline Variabel & PR Crude & PR Adjust-1 & Kesimpulan \\
\hline Umur & 3,408 & 3,163 & $(0,07 \%)=$ Bukan Confounder \\
\hline Masa Kerja & 3,081 & 3,163 & $(-2 \%)=$ Bukan Confounder \\
\hline
\end{tabular}

Tabel 3 menunjukkan bahwa setelah dilakukan uji confounding, diketahui bahwa variabel usia dan masa kerja bukan variabel confounder karena hasil perhitungan $<10 \%$. Namun dalam penelitian ini varia- bel umur tetap dimasukkan dalam model akhir, karena menghasilkan nilai yang positif. Adapun model akhir seperti dalam tabel 4 . 
Tabel 4. Model Akhir dalam Faktor-Faktor yang Mempengaruhi Pelaksanaan Informed Concent di RSUD Dr. M. Yunus Bengkulu Tahun 2011

\begin{tabular}{|c|c|c|c|}
\hline Variabel & Nilai $p$ & PR & 95\%CI \\
\hline Gaya Kepemimpinan & 0,018 & 3,408 & $1,238-9,385$ \\
\hline Usia & 0,136 & 0,451 & $0,158-1,284$ \\
\hline
\end{tabular}

Berdasarkan hasil analisis pada tabel 4 menunjukkan bahwa gaya kepemimpinan mempunyai nilai-p 0,018 (95\% CI $=1,238$ 9,385), sehingga dapat ditarik kesimpulan bahwa gaya kepemimpinan merupakan variabel yang dominan berhubungan dengan pelaksanaan informed concent di RSUD dr. M. Yunus Bengkulu Tahun 2011, setelah dikontrol dengan variabel usia.

\section{PEMBAHASAN}

Informed consent adalah suatu persetujuan dengan klien untuk menerima pengobatan atau prosedur setelah menyediakan informasi lengkap, termasuk manfaat dan risiko pengobatan, alternatif pengobatan, dan prognosis jika tidak dirawat oleh penyedia layanan kesehatan (Dunn, 1999). Berdasarkan hasil penelitian yang telah dilakukan di ruang rawat RSUD Dr. M. Yunus menunjukkan bahwa sebagian besar $(76,8 \%)$ perawat tidak melakukan informed concent dengan lengkap.

Pemberian informed consent merupakan tindakan yang harus selalu dilakukan oleh perawat sebelum melaksanakan tindakan keperawatan. Klien memiliki hak untuk menentukan keputusan tentang perawatan yang mereka terima. Klien dapat mengubah pikiran mereka dan membatalkan prosedur kapan saja karena hak untuk menolak selalu berlaku bahkan setelah menandatangani persetujuan (Sullivan, 1998). Menurut Achadiat (2006) hal-hal yang perlu disampaikan dalam Informed consent adalah maksud dan tujuan tindakan, resiko yang melekat pada tindakan, kemungkinan timbul efek samping, alternatif lain, kemungkinan-kemungkinan (sebagai konsekuensi) yang terjadi bila tindakan tidak dilakukan. Hasil penelitian ditemukan sebagian besar perawat tidak menjelaskan resiko tindakan, efek samping, dan alternatif lain sesuai tujuan tindakan keperawatan yang dilakukan.

Menurut Hall TL dan Meija (1987) dalam Ilyas (2001) faktor yang mempengaruhi pelaksanaan informed consent adalah: faktor internal individu yang terdiri dari: (1) karakteristik individu, seperti: umur, pendapatan, status perkawinan, pengalaman kerja dan masa kerja. (2) Sikap terhadap tugas, seperti: persepsi, pengetahuan, motivasi, tanggung jawab dan kebutuhan terhadap imbalan, sedang faktor eksternal meliputi sosial ekonomi, demografi, geografi, lingkungan kerja, aseptabilitas, aksesabilitas, beban kerja dan organisasi yang terdiri pembinaan, pengawasan, koordinasi, dan fasilitas.

\section{Hubungan Pengetahuan dengan Pelaksa- naan Informed Consent di RSUD Dr. M. Yunus Tahun 2011}

Hasil uji statistik menggunakan chi square $\left(\chi^{2}\right)$ dengan $\alpha=0,05$ menghasilkan $\rho 0,838$. Ini menunjukkan secara statistik tidak terdapat hubungan yang bermakna antara pengetahuan perawat dengan pelaksanaan informed consent dalam melakukan tindakan keperawatan. Hal ini dapat ditunjukkan dari sebagian besar perawat $(80,8$ $\%$ ) yang memiliki pengetahuan baik tidak melakukan informed consent secara lengkap.

Hasil penelitian ini sesuai dengan pendapat Notoatmodjo (2002) bahwa pengetahuan dan sikap tidak selalu akan diikuti oleh adanya tindakan atau perilaku. Hasil penelitian ini tidak sesuai dengan pendapat Kopelman (1998) dalam Ilyas (2001) bahwa pengetahuan akan mempengaruhi perilaku kerja dan produktivitas kerja, baik individu maupun organisasi. Pengetahuan merupakan domain yang 
sangat penting untuk terbentuknya suatu tindakan seseorang (Notoatmojo, 2003).

Menurut Brent Allred (1998) dalam Vitasari (2005) menyarankan lima tipe dari kemampuan (skills), pengetahuan (knowledge), dan sikap (attitude) yang merupakan critical point bagi suksesnya pengembangan karir seseorang, yaitu Technical spesialism termasuk didalamnya pengetahuan terhadap penggunaan komputer, cross-functional dan pengalaman internasional, kepemimpinan kolaboratif, kemampuan mengatur diri sendiri, fleksibilitas termasuk kemampuan untuk memimpin suatu proyek dan menjadi anggota proyek yang lain.

Tidak terdapat hubungan yang signifikan antara pengetahuan perawat dengan pelaksanaan informed consent dikarenakan ada faktor lain yang mempengaruhi kinerja. Menurut Hall TL dan Meija (1987) dalam Ilyas (2001) faktor yang mempengaruhi kinerja adalah: faktor internal individu yang terdiri dari: (1) karakteristik individu, seperti: umur, pendapatan, status perkawinan, pengalaman kerja dan masa kerja. (2) Sikap terhadap tugas, seperti: persepsi, pengetahuan, motivasi, tanggung-jawab dan kebutuhan terhadap imbalan, sedang faktor eksternal meliputi sosial ekonomi, demografi, geografi, lingkungan kerja, aseptabilitas, aksesabilitas, beban kerja dan organisasi yang terdiri pembinaan, pengawasan, koordinasi, dan fasilitas. Dan tidak terdapatnya hubungan yang signifikan antara pengetahuan dengan pelaksanaan informed consent dapat disebabkan karena adanya faktor-faktor yang mempengaruhi pengetahuan, ada dua faktor utama yang mempengaruhi pengetahuan yaitu faktor intrinsik sifat kepribadian, bakat pembawaan, intelegensi, motivasi, usia dan pengalaman, pendidikan, pekerjaan dan informasi. Sedangkan faktor ekstrinsik yaitu lingkungan, agama, kebudayaan.

\section{Hubungan Motivasi dengan Pelaksanaan Informed Consent di RSUD dr. M. Yunus Tahun 2011}

Hasil uji statistik menggunakan chi square $\left(\chi^{2}\right)$ dengan $\alpha=0,05$ menghasilkan $\rho=0,944$. Ini menunjukkan secara statistik tidak terdapat hubungan yang signifikan antara motivasi perawat dengan pelaksanaan informed consent dalam melakukan tindakan keperawatan. Hasil penelitian menunjukkan bahwa tidak ada perbedaan persentase yang terlalu besar antara perawat memilki motivasi rendah dan tinggi dalam melaksanakan inform consent dimana perawat yang memiliki motivasi tinggi dan rendah sama-sama tidak melakukan informed consent yang lengkap.

Hasil penelitian ini tidak sesuai dengan pendapat Mukhlis (2006) yang menyatakan bahwa motivasi mempengaruhi kinerja seseorang, dengan kata lain orang yang memiliki motivasi yang tinggi akan memiliki kinerja yang baik dan sebaliknya orang yang memiliki motivasi yang rendah akan memiliki kinerja yang rendah pula. Motivasi merupakan kondisi mental yang mendorong dilakukannya suatu tindakan (action atau activities) dan memberikan kekuatan (energy) yang mengarah kepada pencapaian kebutuhan, memberi kepuasan ataupun mengurangi ketidakseimbangan. Motivasi tidak ada jika tidak dirasakan rangsangan-rangsangan terhadap hal semacam di atas yang akan menumbuhkan motivasi, dan motivasi yang telah tumbuh memang dapat menjadikan motor dan dorongan untuk mencapai tujuan pemenuhan kebutuhan atau pencapaian keseimbangan (Heidjarachman, dkk, 2007).

Hal ini juga tidak senada dengan pendapat oleh Sarimawar (2003) yang mengatakan bahwa motivasi yang dimiliki oleh tenaga kesehatan berpengaruh dalam pelayanan yang akan diberikan termasuk pemberian informed concent. Tidak terdapat hubungan motivasi dengan pemberian informed concent dapat disebabkan karena informed concent belum memberikan arti yang penting bagi perawat sebagaimana 
yang dikemukan oleh Siagian (2002) bahwa yang diinginkan seseorang dari pekerjaannya pada umumnya adalah sesuatu yang mempunyai arti penting bagi dirinya sendiri dan bagi instansi. Supardi dan Anwar (2004:47) mengatakan motivasi adalah keadaan dalam pribadi seseorang yang mendorong keinginan individu untuk melakukan kegiatan-kegiatan tertentu guna mencapai tujuan. Motivasi yang ada pada seseorang akan mewujudkan suatu perilaku yang diarahkan pada tujuan mencapai sasaran kepuasan. Motivasi merupakan karakteristik psikologis manusia yang memberi kontribusi pada tingkat komitmen seseorang (Nursalam, 2007). Seseorang termotivasi untuk bekerja karena adanya kebutuhan untuk berprestasi. Kebutuhan berprestasi ini bersifat intrinsik dan relatif stabil. Dalam teori ini motivasi merupakan fungsi dari tiga variabel yaitu harapan untuk melakukan tugas dengan berhasil, persepsi tentang nilai tugas dan kebutuhan untuk sukses.

\section{Hubungan Gaya Kepemimpinan dengan Pelaksanaan Informed Consent di RSUD Dr. M. Yunus Tahun 2011}

Hasil uji statistik menggunakan chi square $\left(\chi^{2}\right)$ dengan $\alpha=0,05$ menghasilkan $\rho=0,020$. Ini menunjukkan secara statistik terdapat hubungan yang signifikan antara Gaya Kepemimpinan dengan pelaksanaan informed consent dalam melakukan tindakan keperawatan. Perawat yang yang memiliki persepsi gaya kepemimpinan kepala Ruangan yang demokratis lebih banyak melakukan informed consent dengan lengkap (35\%) dibandingkan perawat yang memiliki persepsi gaya kepemimpinan kepala ruangan otoriter dan partisipatif (14,5\%).

Pelaksanaan Informed consent merupakan salah satu bentuk produktifitas (kinerja) seorang perawat. Gaya kepemimpinan, Secara langsung maupun tidak langsung mempunyai pengaruh yang positif terhadap peningkatan produktivitas kerja karyawan/pegawai. Hal ini didukung oleh Sinungan (1987) yang menyatakan bahwa gaya kepemimpinan yang termasuk di dalam lingkungan organisasi merupakan faktor potensi dalam meningkatkan produktivitas kerja

Batu Bara (1989) menyatakan bahwa produktivitas itu dipengaruhi oleh motivasi dan atos kerja, Keterampilan dan kualitas tenaga kerja, pengupahan dan jaminan sosial. Sedangkan kepemimpinan memainkan peranan yang amat penting, bahkan dapat dikatakan amat menentukan dalam usaha pencapaian tujuan yang telah ditetapkan sebelumnya. Pimpinan membutuhkan orang lain, yaitu bawahan untuk melaksanakan secara langsung tugas-tugas, di samping memerlukan sarana dan prasarana lainnya. Kepemimpinan yang efektif adalah kepemimpinan yang mampu menumbuhkan, memelihara dan mengembangkan usaha dan iklim yang kondusif di dalam kehidupan organisasional.

Bennis (dalam Kartono, 1982) memberi batasan kepemimpinan sebagai “... the process by which an agent induces a subordinate to behave in a desired manner" (proses yang digunakan seorang pejabat menggerakkan bawahannya untuk berlaku sesuai dengan cara yang diharapkan). Dari defenisi di atas dapat dinyatakan bahwa kepemimpinan adalah merupakan proses mempengaruhi atau menggerakkan bawahan (followers) agar mau melaksanakan apa yang diinginkan atau diharapkan oleh pimpinan tersebut hal ini menunjukan bahwa pentingnya peranan pimpinan di dalam kehidupan organisasional.

Ada pakar yang menyebut bahwa "Leadership is getting things done by the others". Seorang pemimpin di dalam melaksanakan kepemimpinan haruslah memiliki kriteria-kriteria yang diharapkan, dalam arti seorang pemimpin harus memiliki kriteria yang lebih dari pada bawahannya misalnya jujur, adil, bertanggung jawab, loyal, energik, dan beberapa kriteria-kriteria lainnya. Kepemimpinan merupakan sebuah hubungan yang kompleks, oleh karena berhadapan dengan kondisi-kondisi ekonomi, nilai-nilai sosial dan pertimbangan politis. 


\section{Hubungan Umur dengan Pelaksanaan Informed Consent di RSUD Dr. M. Yunus Tahun 2011}

Hasil penelitian menunjukkan bahwa lebih dari separuh responden $(55,8 \%)$ berumur $\leq 28$ tahun dan dari hasil analisis bivariat menunjukkan $\mathrm{p}=0,276$ dimana tidak ada hubungan yang bermakna antara umur responden dengan pelaksanaan informed consent dalam melakukan tindakan keperawatan. Hal ini tidak sejalan dengan pendapat Siagian (1999) yang menyatakan bahwa umur mempunyai kaitan yang erat dengan tingkat kedewasaan teknis dan psikologis dalam melaksanakan tugas. Dengan kedewasaan psikologis menunjukkan kematangan jiwa dalam arti semakin bijak, mampu mengendalikan emosi makin mampu berpikir rasional, toleran terhadap pandangan dan perilaku. Selain itu hasil penelitian ini juga bertentangan dengan pendapat Gibson et al (1996) bahwa pekerja yang lebih tua dianggap lebih cakap secara tekhnis.

Bila dikaitkan dengan produktivitas kerja, maka penelitian ini mendukung pernyataan Robbins (1996) yang mengemukakan bahwa ada pengertian yang umum dimana semakin bertambah usia seseorang akan menurunkan produktivitas kerja, dengan kata lain perawat usia yang lebih tua cenderung melakukan tindakan yang sudah terpola sehingga sekalipun pelaksanaan informed consent disadari dapat memberikan banyak manfaat baik bagi pasien maupun bagi perawat namun masih banyak belum dilakukan perawat dalam melakukan tindakan keperawatan.

\section{Hubungan Lama Kerja dengan Pelaksa- naan Informed Consent di RSUD dr. M. Yunus Tahun 2011}

Hasil uji statistik menggunakan chi square $\left(\chi^{2}\right) \alpha=0,05$ menghasilkan $\rho 1,000$, ini menunjukkan secara statistik tidak terdapat hubungan yang signifikan antara lama masa kerja dengan pelaksanaan in- formed consent dalam melakukan tindakan keperawatan.

Hasil penelitian ini sejalan hasil penelitian Leida (1997) di Cianjur, menunjukkan bahwa penurunan kualitas kerja terjadi pada pekerja yang sudah bekerja lebih dari lima tahun. Namun Hasil penelitian ini tidak sesuai dengan pendapat Handoko (2002) bahwa semakin lama seseorang bekerja semakin banyak pengalaman dan pelajaran yang dijumpai sehingga sudah mengerti apa keinginan dan harapan. Serta bertentangan dengan pendapat Heidjrachman (2007) bahwa lama masa kerja seseorang berpengaruh terhadap hasil dan suatu pekerjaan dan penguasaan terhadap suatu pekerjaan, begitupun terhadap pemberian pelayanan kesehatan terhadap klien, ini juga dipengaruhi oleh lama masa kerja dan tenaga kesehatan sendiri.

David (1994) dalam Djati dan Khusaini (2003) menyatakan bahwa masa kerja dapat mempengaruhi tenaga kerja baik positif maupun negatif. Akan memberikan pengaruh positif kepada tenaga kerja dimana dengan lamanya seseorang bekerja maka dia akan semakin berpengalaman dalam melakukan tugasnya. Sebaliknya dapat juga memberikan pengaruh negatif dimana semakin lamanya seseorang bekerja maka akan menimbulkan kebosanan (Tulus MA, 1992). Hal ini dapat dilihat dari hasil penelitian yang menunjukkan bahwa baik perawat yang kategori baru dan perawat yang sudah lama bekerja sebagian besar tidak melakukan informed consent dengan lengkap. Hal ini dikarenakan perawat yang baru belum memiliki banyak pengalaman dan kemampuan berinteraksi yang baik sedangkan perawat yang lama dapat disebabkan faktor kebosanan dalam bekerja. Menurut pendapat Brent Allred (1998) dalam Vitasari (2005), disaat seseorang tidak mendapatkan kepuasan dalam pekerjaan, merasakan stress dalam melakukan pekerjaan, tidak mendapatkan kesempatan pengembangan karir dan kompensasi yang sesuai, seseorang akan merasa bosan dan tidak termotivasi atau tidak mempunyai keinginan untuk memberikan pelayanan 
yang baik, sehingga hal-hal tersebut dapat mempengaruhi perawat untuk memberikan informed consent secara lengkap.

Hubungan Jenis Kelamin dengan Pelaksanaan Informed Consent di RSUD Dr. M. Yunus Tahun 2011

Hasil penelitian menemukan sebagi-an besar $(73,1 \%)$ responden berjenis kelamin wanita, dan dari analisis bivariat diperoleh hasil $\mathrm{p}=0,960$ yang berarti tidak ada hubungan yang signifikan antara jenis kelamin dengan pelaksanaan informed concent di RSUD M.Yunus. Hasil penelitian ini sejalan dengan pendapat Robbis (2003) yang mengatakan tidak ada perbedaan yang konsisten antara wanita dan pria dalam kemampuan memecahkan masalah. Dengan banyaknya pekerja wanita menunjukkan peningkatan partisipasi wanita dalam angkatan kerja sehingga diasumsikan bahwa tidak ada perbedaan berarti dalam produktivitas pekerjaan antara wanita dan pria. Sama halnya tidak ada bukti yang menunjukkan jenis kelamin karyawan mempengaruhi kepuasan kerja.

Faktor Dominan yang Berhubungan dengan Pelaksanaan Informed Consent di RSUD Dr. M. Yunus Tahun 2011

Hasil akhir uji multivariat didapatkan satu variabel yang berpengaruh terhadap pelaksanaan informed consent oleh perawat di ruang rawat inap RSUD M.Yunus Bengkulu. Variabel tersebut adalah gaya kepemimpinan dengan nilai p 0,018, sedangkan variabel umur dianggap sebagai variabel confounding.

Gaya kepemimpinan kepala ruangan yang otoriter dan partisipatif mempunyai

\section{DAFTAR KEPUSTAKAAN}

Achadiat, C. 2006. Dinamika Etika dan Hukum Kedokteran dalam Tantangan Zaman, Penerbit Buku Kedokteran, EGC, Jakarta.

Alimul, A. 2003. Riset Keperawatan Penerbit. Jakarta : Salemba Medika. Edisi 1.

Andriani, Henny. 2007. Hubungan Tatalaksana Informed Consent (Persetujuan Tindakan risiko sebesar 3,408 kali (95\% CI: 1,2389,385) untuk perawat pelaksana melaksanakan informed consent secara tidak lengkap, dibandingkan gaya kepemimpinan demokratis, setelah dikontrol dengan umur, di ruang rawat inap RSUD Dr. M. Yunus Bengkulu tahun 2011.

Sesuai dengan pendapat Batubara (1989), kepemimpinan memainkan peranan yang amat penting bahkan dapat dikatakan amat menentukan dalam usaha pencapaian tujuan yang dalam hal ini adalah kinerja perawat dalam melakukan tindakan yaitu pemberian informed consent.

Gaya kepemimpinan, secara lang-sung maupun tidak langsung mempunyai pengaruh yang positif terhadap peningkatan produktivitas kerja karyawan/pegawai. Hal ini didukung oleh Sinungan (1987) yang menyatakan bahwa gaya kepemimpinan yang termasuk di dalam lingkungan organisasi merupakan faktor potensi dalam meningkatkan produktivitas kerja.

Pendapat serupa juga dikemukakan oleh Gibson et al (1996) bahwa pekerjaan yang lebih tua dianggap lebih cakap secara teknis. Oleh sebab itu perawat yang lebih tua diharapkan mampu melaksanakan informed consent secara lengkap, setiap sebelum melaksanakan tindakan keperawatan. Hasil penelitian ini menganggap bahwa umur merupakan variabel confounding antara gaya kepemimpinan dengan pelaksanaan informed consent di RSUD Dr. M. Yunus Bengkulu Tahun 2011. Umur menunjukkan kedewasaan, diharapkan semakin dewasa seseorang, maka semakin baik pelaksanaan tindakan keperawatannya termasuk diantaranya adalah pelaksanaan informed concent.

Medis) dengan Tingkat Pengetahuan Pasien/Keluarga Tentang Tindakan Medis Di Ruangan rawat inap Seruni RSUD,Dr M.YUNUS Bengkulu 2007. Skripsi Sarjana prodi Kesehatan Masyarakat . Tidak di Publikasikan.

Arikunto. 1998. Prosedur Penelitian Suatu Pendekatan Praktek. Jakarta. Rineka Cipta. 
2002. Prosedur Penelitian Suatu Pendekatan Praktek. Jakarta : PT Rineka Cipta. Depkes RI. 2001. Standar Pelayanan Rumah Sakit, Cetakan V. Jakarta.

Ayuningtyas, 2005. Manajemen Strategik. Jakarta : FKM UI $\operatorname{lm} 21-54$.

Hafi. 2006. Peningkatan Kemampuan Berbicara Siswa Kelas Satu MTS Sunan Kalijaga Malang Melalui Strategi Pemetaan Pikiran, Jakarta.

Hamzah. 2007. Teori Motivasi dan Pengukurannya, Bumi Aksara, Jakarta.

Heidjarachman, dkk. 2007. Memberi Motivasi Kerja Terhadap Karyawan, Jakarta.

Ilyas, Y. 2001. Kinerja : Teori penilaian dan penelitian, Depok : Pusat Kajian Ekonomi Kesehatan FKM-UI.

Kariyoso. 1994 . Pengantar komunikasi bagi siswa perawat,Jakarta: EGC.

Kozier, dkk. 2002. Praktik keperawatan profesional : konsep \& perspektif, Ed. 4, Jakarta.

Notoatmodjo. 2002. Metodologi Penelitian Kesehatan. Jakarta: Rineka Cipta.

Notoatmodjo. 2003. Pengantar Pendidikan Kesehatan dan Ilmu Prilaku Kesehatan. Yogyakarta: Andi Ofset Notoatmodjo. 2005. Metodologi Penelitian Kesehatan. Jakarta: Rineka Cipta.

Nursalam. 2001. Proses dan Dokumentasi Keperawatan : Konsep dan Praktik. Jakarta : Salemba Medika.

Nursalam. 2002. Manajemen Keperawatan, Aplikasi dalam Praktik Keperawatan Profesional. Jakarta : Salemba Medika.

Nursalam. 2003. Metodelogi Penelitian Ilmu Keperawatan. Jakarata: Salemba Medika.
Politekhnik Kesehatan Bengkulu, 2007. Buku Pedoman Penulisan Karya Tulis Ilmiah, Bengkulu.

Potter \& Perry. 1999. Buku Ajar Fundamental Keperawatan: Konsep, Proses, dan Praktik, Vol. I, E/4. Alih bahasa: Yasmin Asih, dkk, Jakarta: Buku Kedokteran EGC.

Sarimawar, D. 2003. Penyakit Penyebab Kematian Bayi Baru Lahir (Neonatal) dan Sistem Pelayanan Kesehatan Yang Berkaitan di Indonesia,

Nursalam. 2008. Pendidikan dan Keperawatan. Jakarta : Salemba Medika.

Badan Litbang Kesehatan, Jakarta, Tanggal 15 Februari 2008.

Sondang.P, 1998. Manajemen Sumber Daya Manusia. Jakarta : Bumi Aksara.

Siagian, Sondang.P, 1998. Manajemen Sumber Daya Manusia. Jakarta : Bumi Aksara.

Stuart, G. W. Dan sundeen, S. J. 1998. Principles and Practise of Psychiatric Nursing ( $6^{\text {th }}$ ed). St. Louis : The C.V. Mosby Company

Suprihanto, J., TH.A.M.Harsiwi, P.Hadi, 2003, Perilaku Organisasi, Yogyakarta: Sekolah Tinggi Ilmu Ekonomi Yayasan Keluarga Pahlawan Negara, hlm 21-54.

Swanburg, 2000. Kepemimpinan dan Manajemen Keperawatan. Jakarta : EGC

Siagian, Sondang.P, 1998. Manajemen Sumber Daya Manusia. Jakarta : Bumi Aksara.

Stuart, G. W. Dan sundeen, S. J. 1998. Principles and Practise of Psychiatric Nursing $\left(6^{\text {th }}\right.$ ed). St. Louis : The C.V. Mosby Company

Suprihanto, J., TH.A.M.Harsiwi, P.Hadi, 2003, Perilaku Organisasi, Yogyakarta: Sekolah Tinggi Ilmu Ekonomi Yayasan Keluarga Pahlawan Negara, h

Swanburg, 2000. Kepemimpinan dan Manajemen Keperawatan. Jakarta : EGC 